\title{
Notice of Authorship Retraction
}

\section{Use of prophylactic inferior vena cava filters in trauma}

\author{
إشعار عن تراجع المؤلف \\ الاستخدام الوقائي لمرشحات الوريد الأجوف السفلي في حالات الإصابات والصدمات
}

\begin{abstract}
NOTICE OF AUTHORSHIP RETRACTION FOR: NAIEM ET AL. USE OF PROPHYLACTIC
INFERIOR VENA CAVA FILTERS IN TRAUMA. SULTAN QABOOS UNIV MED J 2016; 16:E82-5. DOI: 10.18295/SQUMJ.2016.16.01.015.
\end{abstract}

The Editors of Sultan Qaboos University Medical Journal (SQUMJ) have been informed that one of the authors of an article by Naiem et al. in the February 2016 issue of SQUMJ, Alreem K. Al-Hinai, wishes to retract their authorship from the above article. ${ }^{1}$

Al-Hinai initially submitted the article to SQUMJ in January 2015 and was intended to be the first/corresponding author. However, due to her busy schedule, she was unable to contribute significantly. In December 2015, Al-Hinai informed the Editors of SQUMJ that Ahmed Naeim was the author responsible for the majority of the work on this article and that her contribution was negligible; at her request, Naeim was designated by the Editors of SQUMJ as the first and corresponding author of the article. In April 2016, Al-Hinai contacted the Editors of SQUMJ stating that she wished to retract her authorship of the above article as she does not fulfil the four criteria of authorship as defined by the International Committee of Medical Journal Editors. ${ }^{2}$

For the reasons stated herein, the Editors of SQUMJ wish to notify readers that the authorship of Al-Hinai is hereby retracted from the above article. Al-Hinai takes sole responsibility for this retraction notice and would like to apologise to the readers, reviewers and editors of SQUMJ for retracting her authorship after publication. However, in the interest of scholarly ethics, she does not wish for her name to be attributed to a publication without having contributed significantly to the research in question.

\section{References}

1. Naiem AA, Al-Hinai AK, Al-Sukaiti R, Al-Qadhi H. Use of prophylactic inferior vena cava filters in trauma. Sultan Qaboos Univ Med J 2016; 16:e82-5. doi: 10.18295/squmj.2016.16.01.015.

2. International Committee of Medical Journal Editors. Defining the role of authors and contributors. From: www.icmje.org/recommendations/ browse/roles-and-responsibilities/defining-the-role-of-authors-and-contributors.html Accessed: May 2016. 